\title{
Çocukluk Döneminde Yaşanan İhmal veya İstismarın Benlik Saygısına Etkisinin
}

\author{
Íncelenmesi
}

\section{Examination of the Effects of Childhood Experience of Neglect or Abuse and Self-Esteem}

\author{
Güliz ONAT ${ }^{\mathrm{a}}$, Hüsniye DİNÇ ${ }^{\mathrm{b}}$, Sevil GÜNAYDINc, Figen UĞURLU ${ }^{\mathrm{d}}$
}

\begin{abstract}
ÖZET Amaç: Kız öğrencilerin çocukluk döneminde ihmal veya istismara maruz kalma durumu ile benlik saygısı arasındaki ilişkiyi değerlendirmektir. Gereç ve Yöntem: Tanımlayıcı ve ilişki arayıcı özellikteki bu çalışma ebelik ve hemşirelik bölümünde öğrenim gören 335 kız öğrenci üzerinde gerçekleştirilmiş̧ir. Verilerin toplanmasında Coopersmith Benlik Saygısı Ölçeği ve anket formu kullanılmışırı. Veriler yüz yüze görüşme yöntemi ile toplanmıştır.

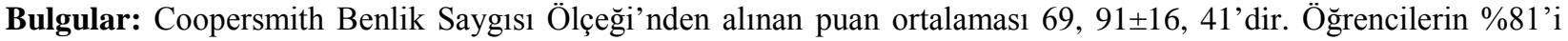
çocukluk döneminde ebeveynlerinin sinirliyken bağırıp azarladığını, \%74'ü ise isteklerinin göz ardı edildiğini bildirmişlerdir. Buna rağmen katılımcıların çoğunluğu aileleri tarafından beslenmeye özen gösterildiğini ve sevildiğini bildirmişlerdir. Sonuç: Çalışma grubumuzda kız öğrencilerin benlik saygılarının orta düzeyde olduğu; duygusal ve fiziksel yönden ihmal edilen öğrencilerin bulunduğu ve bu öğrencilerin benlik saygılarının istatistiksel olarak anlamlı şekilde daha düşük olduğu belirlenmiştir.
\end{abstract}

Anahtar Kelimeler: Benlik saygısı, çocukluk dönemi, ihmal, istismar

ABSTRACT Aim: The aim of the present study is to assess the relationship between female students' experience of childhood neglect or abuse and self-esteem. Material and Methods: The current descriptive and correlational study was conducted among 335 female students who were studying nursing/midwife. "Coopersmith Self-Esteem Inventory" and questionnaire form was used to collect data. The data were obtained via face-to-face interview. Results: The mean Coopersmith Self-Esteem Inventory score was $69,91 \pm 16$, 41. Of the students, $81 \%$ reported being exposed to scold and $74 \%$ neglected by their parents and in childhood period. Despite this, most of the participants reported to paid attention on nutrition and loved by their parents. Conclusion: The results reveal that female students in the sample have a medium level of self-esteem, there are some students who have experienced emotional and physical neglect, and students who experienced emotional and physical neglect have significantly lower self-esteem scores than those did not.

Key words: Abuse, childhood, neglect, self-esteem

Geliş Tarihi/Received: 2015-07-31/ Kabul Tarihi/Accepted: 2015-11-27

a Doç. Dr., E-mail: gulizonat@hotmail.com

b Sorumlu Yazar / Correspondence Dr., İstanbul Üniversitesi Sağlık Bilimleri Fakültesi Ebelik Bölümü Demirkap1

Cad. Karabal Sk. Bakırköy Ruh ve Sinir Hastalıkları Hastanesi Bahçesi içi 34740 Bakırköy/İstanbul E-mail: husniyedinc@hotmail.com

${ }^{c}$ M.Sc., İstanbul Üniversitesi Sağlık Bilimleri Fakültesi Ebelik Bölümü Demirkapı Cad. Karabal Sk. Bakırköy Ruh ve Sinir Hastalıkları Hastanesi Bahçesi içi 34740 Bakırköy/İstanbul E-mail:svlgunaydin@hotmail.com

d M.Sc., E-mail :fugurluyum@hotmail.com

Atıf: Onat G, Dinç H, Günaydın S, Uğurlu F. Çocukluk Döneminde Yaşanan İhmal veya İstismarın Benlik Saygısına Etkisinin İncelenmesi. HSP 2016;3(1): 9-15.

To cite this article: Onat G, Dinç H, Günaydın S, Uğurlu F. Examination of the Effects of Childhood Experience of Neglect or Abuse and Self-Esteem. HSP 2016;3(1): 9-15. 


\section{GíRiș}

Çocuk istismarı ve ihmali ana, baba ya da bakıcı gibi bir erişkin tarafından çocuğa yöneltilen, toplumsal kurallar ve profesyonel kişilerce uygunsuz ya da hasar verici olarak nitelendirilen, çocuğun gelişimini engelleyen ya da kısıtlayan eylem ve eylemsizliklerin tümüdür. ${ }^{1}$ On sekiz yaş altı çocuklara yapılan kötü muamele; istismar ve ihmaldir. Bu da çocukların sağlığına, yaşamına, gelişimine, saygınlığına mevcut veya olası zarar ile sonuçlanan her türlü fiziksel, duygusal, cinsel istismar ve ihmali kapsar. Uluslararası çalışmalarda her beş kadından birinin ve her on üç erkekten birinin çocukluğunda cinsel tacize maruz kaldığ 1 , tüm yetişkinlerin ise dörtte birinin çocukluğunda fiziksel istismara maruz kaldıkları bildirilmektedir. $^{2}$

İstismar sadece olayın yaşandığı zaman süreci içinde değil kişinin hayatında uzun yıllar etkisini koruyan bir durumdur. Çocukların kendilerini en fazla güvende hissedecekleri yer aile ortamı olmasına rağmen, en çok risk altında kaldıkları yer de yine aile ortamıdır. ${ }^{1}$ Çocukların aile içinde istismara maruz kalmalarını; ebeveynlerin özellikleri, sosyal sorunlar, ebeveyn ile çocuk arasındaki sağlıksız etkileşim ve çocuğun gelişimsel sorunları etkilemektedir. Ayrıca düşük sosyo-ekonomik seviye, yaşam alanının yeterli olmaması, geniş aile yapısı, göç varlığı, parçalanmış aile, ebeveynlerin mutsuz evlilikleri, ebeveynlerde madde kullanım öyküsünün varlığg çocuğa yönelik ihmal ve istismarın ortaya çıkmasında etkili olan faktörler olarak bildirilmektedir. ${ }^{3,4}$

İstismar ve ihmalin, çocuklar üzerindeki kısa ve uzun süreli sonuçlarını ortaya koymak için yapılan çoğu araştırmada çocuğun davranışsal, sosyal, bilişsel ve duygusal problemin ortaya çıktığı tespit edilmiştir. ${ }^{5}$ Bu problemler; güvensiz bağlanma, düşük benlik saygısı, düşük okul başarısı, davranışsal problemler, suça eğilim, yeme bozuklukları, cinsel sağlık problemleri, madde kullanımı, majör depresyon gibi olumsuzluklardır. ${ }^{5,6}$

Benlik saygısı; kişinin kendini değerlendirmesi sonucunda ortaya çıkan beğeni durumudur. Benlik saygıs1, bireyin kendisini olduğundan aşağ 1 ya da üstün görmeksizin kendinden memnun olma durumudur. ${ }^{7}$ Kişi kendini eleştirebilir ya da kendini tümden olumlu bulabilir. Kişinin kendini beğenmesi, benliğine sayg1 duyması için üstün özelliklerinin olması gerekmez. ${ }^{8}$ Arkadaşlar ve aileden alınan sosyal destekle benlik saygisı artar. $^{9}$ Benlik saygisı öğrenilen bir fenomen ve yaşam boyu devam eden bir süreçtir. Beden imgesi (gerçek benlik), ailede ebeveynlerin çocuğa ilişkin sözel ya da sözel olmayan davranışlarıyla oluşur ve yaşamın ilk yıllarında gelişmeye başlar. Ebeveynlerin çocukla etkileşimi, çocuğun aile içindeki yerini belirler. Çocuğun bakımı, eğitimi ve çocuğun sosyalleştirilmesi anne babanın en önemli görevleri arasındadır. Ayrıca koruma, güven duygusu kazandırma ve topluma uyumlu bir kişilik geliştirmesini sağlama işlevleri de bulunmaktadır. Dolayısıyla çocuğun fizyolojik ve psikolojik gelişimin de aile önemli rol oynamaktadır. ${ }^{10}$ Çocukluk yaşantılarında ihmal ve istismar öyküsü bulunan yetişkinler ruhsal sorunlar açısından daha yüksek risk altındadırlar. ${ }^{11}$

Benlik saygısının gelişmeye başladığı çocukluk döneminde istismar ve ihmal edilen çocukların benlik saygıları olumsuz etkilenebilmektedir. K1z çocukları çocukluk döneminde cinsiyetlerinden ötürü daha fazla istismar ve ihmale maruz kalmaktadır. Bu çalışmanın amacı kız öğrencilerin çocukluk döneminde istismara veya ihmale maruz kalma durumlarını belirlemek ve bu durumun benlik saygisına etkisini değerlendirmektir. $\mathrm{Bu}$ doğrultuda araştırma soruları;

1. Çocukluk döneminde yaşanan ihmal ve istismar benlik saygısını etkiler mi?

2. Çocukluk döneminde yaşanan ihmal ve istismar nasıldır?

3. Örneklem grubunun benlik saygısı düzeyi nedir?

\section{GEREÇ VE YÖNTEM}

\section{Araştırmanın Tasarımı, Yapıldığı Yer ve} Zaman

Araştırma, Sağlık Yüksekokulu’nda 2007-2009 yılları arasında gerçekleştirilmiş olup tanımlayıcı ve ilişki arayıcı tipte planlanmıştır.

\section{Evren ve Örneklemi}

Araştırmanın evrenini, Sağlık Yüksekokulu'nda 2007-2009 yılları arasında ebelik ve hemşirelik bölümünde öğrenim gören tüm kız öğrenciler oluşturmuştur. Araştırmanın örneklemini ise; belirtilen zaman dilimi içerisinde eğitim gören ve 
araştırmaya katılmayı kabul eden toplam 335 k1z öğrenci oluşturmaktadır.

\section{Veri Toplama Araçları ve Uygulanması}

Çalışma kapsamına verilerin toplanmasında araştırmacılar tarafindan literatür doğrultusunda geliştirilen "Tanıtıcı Bilgi Formu" ve "Coopersmith Benlik Saygısı Ölçeği" kullanılmıştır.

Tanitıcı Bilgi Formu: Araştırmacılar tarafından literatür doğrultusunda geliştirilen tanıtıc1 bilgi formunda öğrencilerin sosyodemografik özelliklerini içeren 15 soru ile çocukluk döneminde yaşanılan istismar ve ihmal durumlarını değerlendiren 18 soru yer almaktadır.

Coopersmith Benlik Saygısı Ölçeği (CBSÖ): Stanley Coopersmith tarafindan 1975 yılında geliştirilen, özellikle yetişkinlere olmak üzere çeșitli yaș gruplarına uygulanabilecek bir ölçektir. Türkiye'de ölçek Tufan ve Turan (1987) tarafından Türkçe’ye uyarlanarak, geçerlilik ve güvenilirliği yapılmıştır. Ölçek "benim gibi” ve "benim gibi değil" şeklinde yanıt seçenekleri bulunan 25 ifadeden oluşmaktadır. Ölçeğin puanlaması; her doğru ifade için " 4 ", yanlış ifade için ise " 0 " puan olarak belirlenmiştir. Ölçekten en yüksek 100 puan, en düşük puan ise 0 puan alınabilmektedir. Ölçekten elde edilen toplam puan, 10-30 arasında ise düşük, 31-70 arasında ise orta, 71-100 arasında ise yüksek benlik saygısı olarak tanımlanmaktadır. Tufan tarafindan ölçeğin alfa katsayısı r=0.62 olarak bulunmuştur. Yine Turan ve Tufan'ın birer yıl arayla yapmış oldukları çalışmalarda ölçeğin test-tekrar test güvenirliliği $\mathrm{r}=0.65, \mathrm{r}=0.76$ olarak saptanmıştır. 10,12

Verilerin toplanmasında yüz yüze görüşme yöntemi kullanılmış ve her katılımcının bilgi formunu kendisinin yanitlaması sağlanmıştır.

\section{Verilerin Değerlendirilmesi}

Araştırma sonuçları ortalama \pm standart sapma ya da sayı (yüzde) olarak gösterilmiştir. Ayrıca verilerin değerlendirilmesinde ki-kare, $t$ test ve Anova testi kullanılmıştır. Verilerin normal dağılıp dağılmadığını görmek amaciyla ShapiroWilk testi uygulanmış ve tüm grupların \%95 güvenle normal dağıldığı saptanmıştır.

\section{Araştırmanın Etik İlkeleri}

Araştırmanın yapılabilmesi için Sağlık Yüksekokulu Müdürlüğü'nden izin alınmıştır. Araştırmayı kabul eden öğrenci ebe ve hemşirelerden sözlü onay alınmıştır.

\section{BULGULAR}

Çalışma kapsamına alınan katılımcıların $(n=335)$ ve ebeveynlerinin tanitıcı özellikleri incelendiğinde (Tablo 1), katılımcıların yaş ortalamasının 20,37 $\pm 1,80$ olduğu, çoğunluğunun çekirdek aile tipine (\%82) sahip, geliri giderine denk (\%69), annelerin eğitiminin en fazla ilkokul (\%53), babaların eğitiminin ise en fazla ortaokul ve üzeri $(\% 54,4)$ olduğu saptanmıştır.

Katılımcılara CBSÖ uygulanmıştır. Ölçekten alınan puanlar 16-100 arası değişmekte olup; ortalamasi $69,91 \pm 16,41 \quad$ olarak belirlenmiştir. Tablo 2'de ölçek puanlarının dağılımlarına yer verilmiștir.

Katılımcıların çocukluk döneminde istismar ve ihmal edilme durumlar1 değerlendirilmiş ve her bir ifade CBSÖ toplam puan ortalamalarıyla karşılaştırılmıştır (Tablo 3). Buna göre; ebeveynleri tarafindan tokata, azarlanmaya, korkutulmaya, tehdide, toplum önünde küçük düşürülmeye maruz kalan; kişisel bakımına ve beslenmesine özen gösterilmeyen, ev ödevlerine yardım edilmeyen, sevildiği belli edilmeyen öğrencilerin benlik saygısı puanlarının istatistiksel olarak daha düşük olduğu belirlenmiștir (Tablo 3).

İstismar ve ihmal edilme durumları arasında dikkati çeken önemli bulgular öğrencilerin \%81'i ( $n=271)$ çocukluk döneminde ebeveynleri tarafından bağırıp azarlanması, \%74'ü $(n=248)$ isteklerinin göz ardı edilmesi, \%36's1 (n=121) kendisine tokat atılmasıdır. Ayrıca öğrencilerin \%23'ünün $(n=77)$ bazen veya her zaman tehdit edildiği ve toplum önünde küçük düşürüldüğü, \%43'ünün $(\mathrm{n}=144)$ korkutulduğu, \% 34'ünün (114) kötü söze maruz kaldığını ve $\% 8$ 'inin $\quad(n=27)$ evde yalnız birakıldığ saptanmıştır.

Buna rağmen öğrencilerin neredeyse tamamı bazen veya her zaman beslenmesine gerekli özenin gösterildiğini $(\% 99, \quad n=332)$, sevildiğinin belli edildiğini $(\% 98, \quad n=328)$, hastalık durumunda doktora götürüldügünü (\%98, $\mathrm{n}=328), \quad$ kişisel bakımına özen gösterildiğini $(\% 96, n=321)$ ve ev ödevlerini 
yapmasına yardımcı olunduğunu $(\% 88, n=294)$ belirtmişlerdir.

CBSÖ toplam puan ortalaması ile yaş grupları (20 ve alt1; 21 ve üzeri) karşılaştırıldığında istatistiksel olarak anlamlı ilişkinin olmadığ belirlenmiştir $(\mathrm{t}=-2,10 ; \mathrm{p}=$ 0,36). CBSÖ toplam puan ortalaması ile kardeş sayıs $(F=0,35 ; p=0,69)$ arasinda anlamlı bir fark saptanmamıştır.

Tablo 1. Katılımcıların ve ebeveynlerinin tanıtıcı özellikleri

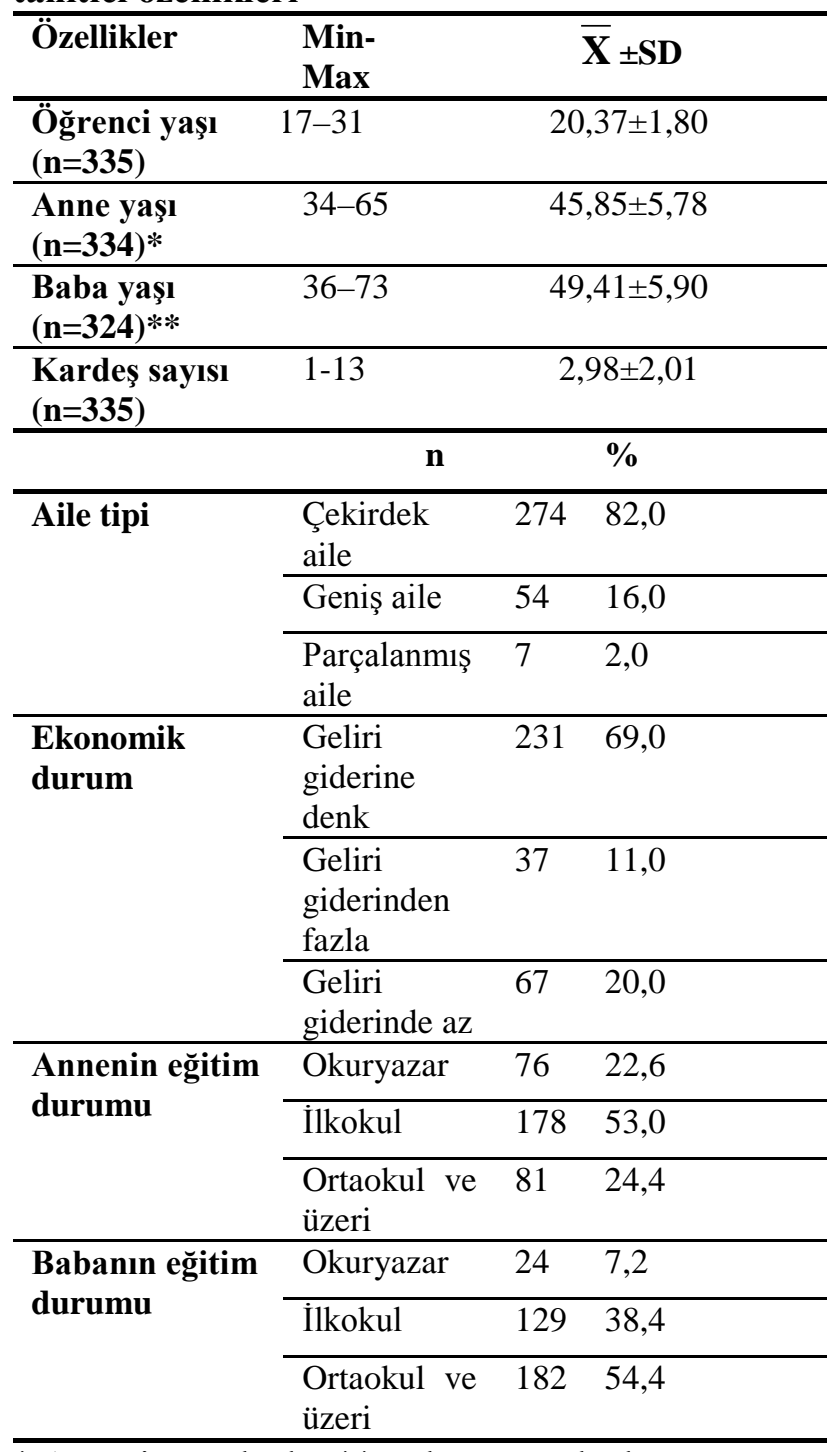

* Annesi sağ olanlar ** Babası sağ olanlar
Tablo 2. Benlik saygısı ölçek puanlarının dağılımı

\begin{tabular}{lrr}
\hline Sinıflandırma & $\mathbf{n}$ & $\mathbf{\%}$ \\
\hline 10-30 Düşük & 7 & 2,1 \\
\hline 31-70 Orta & 142 & 42,4 \\
\hline 71-100 Yüksek & 186 & 55,5 \\
\hline Toplam & $\mathbf{3 3 5}$ & $\mathbf{1 0 0 , 0}$ \\
\hline
\end{tabular}

\section{TARTIŞMA}

Çocukluk dönemi benlik saygısının gelişimi açısından önemli bir dönem olarak ifade edilebilir. ${ }^{13}$ Çalışmada öğrencilerin CBSÖ'nden aldıkları puanlar doğrultusunda benlik saygilarının orta düzeyde $(69,91 \pm 16,41)$ olduğu belirlenmiştir. Benzer şekilde hemşirelik öğrencilerinin CBSÖ puan ortalamaları Taysi'nin (2000) çalışmasında $65,6 \pm 16,9$; Kahriman'ın (2006) çalışmasında $69,1 \pm 17,3$, Karadağ ve ark. (2008) çalışmasında $69,13 \pm 15,5$; Torun ve ark. (2012) çalışmasında 68,56 $\pm 18,27$ olarak belirlenmiştir. ${ }^{8-10,14}$ Ancak Özkan ve Özen'in (2008) 322 hemşirelik öğrencisi ile yaptığı çalışmasında öğrencilerin \%65'inin, Dinçer ve Öztunç'un (2009) 409 ebe ve hemşire öğrenciler ile yaptığ 1 çalışmasında ise \%61,4'ünün benlik saygısının yüksek olduğu saptanmıştır. ${ }^{13,15}$ Literatürdeki çalışmalarda benlik saygisı ortalamaları değişiklik göstermektedir.

Genellikle disiplin ve cezalandırma amaciyla uygulanan dayağın Türkiye'de de yaygin olduğu ve en sik gerçekleşen fiziksel istismar şeklinin ise tokat atarak cezalandırma olduğu bildirilmektedir. ${ }^{16}$

Çalışmaya katılan öğrencilerin \%37'si çocukluğunda kendisine tokat atıldığını bildirmiştir. Çetinkaya (2013)'nın çalışmasında üniversite öğrencilerinin \% 26,3'ü fiziksel şiddete maruz kaldığını; Ayan (2011)'ın ilköğretim öğrencileri ile yapmış olduğu çalışmada ise öğrencilerin \%27,5'i annesi tarafından, \%14,2'si babası tarafindan tokat atıldığını belirtmişlerdir. ${ }^{17,18}$ Bilge ve ark. (2013)'nın ebeveynlerle yaptıkları çalışmasında çocukların zaman zaman dayağı hak ettiklerini belirten annebabaların oranı $\% 17,4$ olarak saptanmıştır. ${ }^{19}$ 
Tablo 3. Katılımcıların çocukluk döneminde istismar ve ihmal edilme durumları ile CBSÖ puan ortalamalarının karşılaştırılması

\begin{tabular}{|c|c|c|c|c|c|c|c|c|}
\hline $\begin{array}{l}\text { İstismar/İhmal Edilme } \\
\text { Durumları }\end{array}$ & $\begin{array}{c}\text { Her } \\
\text { zaman } \\
\%\end{array}$ & $\begin{array}{l}\text { CBSÖ } \\
\bar{X}_{ \pm \text {SD }}\end{array}$ & $\begin{array}{c}\text { Bazen } \\
\%\end{array}$ & $\begin{array}{l}\text { CBSÖ } \\
\bar{X}_{ \pm \text {SD }}\end{array}$ & $\begin{array}{c}\text { Asla } \\
\%\end{array}$ & $\begin{array}{l}\text { CBSÖ } \\
\bar{X}_{ \pm S D}\end{array}$ & $\mathbf{F}$ & $\mathbf{P}$ \\
\hline $\begin{array}{l}\text { İsteklerinizi göz ardı } \\
\text { etme }\end{array}$ & 2,0 & $64,57 \pm 22,55$ & 72,0 & $69,28 \pm 15,84$ & 26,0 & $69,91 \pm 16,41$ & 1,30 & 0,27 \\
\hline $\begin{array}{l}\text { Hastalık durumunda } \\
\text { doktora götürme }\end{array}$ & 78,0 & $63,00 \pm 15,52$ & 20,0 & $67,04 \pm 18,87$ & 2,0 & $70,86 \pm 15,67$ & 2,18 & 0,11 \\
\hline Sinirliyken tokat atma & 6,0 & $62,66 \pm 22,66$ & 30,0 & $67,18 \pm 16,45$ & 64,0 & $71,83 \pm 15,49$ & 4,74 & $0,00^{*}$ \\
\hline $\begin{array}{l}\text { Sinirliyken bağırıp } \\
\text { azarlama }\end{array}$ & 9,0 & $60,12 \pm 20,82$ & 72,0 & $70,27 \pm 15,63$ & 19,0 & $73,46 \pm 15,31$ & 7,29 & $0,00^{*}$ \\
\hline Korkutma & 4,0 & $61,33 \pm 21,57$ & 41,0 & $68,94 \pm 14,32$ & 55,0 & $71,32 \pm 15,83$ & 3,00 & $0,05^{*}$ \\
\hline Tehdit etme & 4,0 & $68,33 \pm 18,36$ & 19,0 & $63,49 \pm 19,08$ & 77,0 & $71,53 \pm 15,25$ & 6,34 & $0,00^{*}$ \\
\hline Kötü söz söyleme & 4,0 & $67,33 \pm 21,69$ & 30,0 & $69,30 \pm 17,93$ & 66,0 & $70,32 \pm 15,41$ & 0,28 & 0,75 \\
\hline $\begin{array}{l}\text { Evde yalnız birakarak } \\
\text { cezalandırma }\end{array}$ & 1,0 & $72,00 \pm 28,28$ & 7,0 & $68,86 \pm 19,70$ & 93,0 & $69,97 \pm 16,15$ & 0,64 & 0,93 \\
\hline $\begin{array}{l}\text { Toplum önünde küçük } \\
\text { düşürme }\end{array}$ & 5,0 & $69,06 \pm 21,08$ & 18,0 & $62,64 \pm 18,19$ & 77,0 & $71,70 \pm 15,20$ & 7,95 & $0,00^{*}$ \\
\hline $\begin{array}{l}\text { Kişisel bakıma özen } \\
\text { gösterme }\end{array}$ & 81,0 & $61,84 \pm 18,51$ & 15,0 & $64,23 \pm 18,66$ & 4,0 & $71,36 \pm 15,56$ & 5,84 & $0,00^{*}$ \\
\hline $\begin{array}{l}\text { Ev ödevlerine yardım } \\
\text { etme }\end{array}$ & 42,0 & $64,41 \pm 21,08$ & 46,0 & $69,22 \pm 16,15$ & 12,0 & $72,16 \pm 14,87$ & 3,73 & $0,02^{*}$ \\
\hline Sevdiğini belli etme & 70,0 & $72,57 \pm 12,52$ & 28,0 & $65,33 \pm 17,46$ & 2,0 & $71,64 \pm 15,77$ & 5,14 & $0,00^{*}$ \\
\hline $\begin{array}{l}\text { Beslenmeye gereken } \\
\text { özeni gösterme }\end{array}$ & 86,0 & $54,00 \pm 30,37$ & 13,0 & $64,08 \pm 18,57$ & 1,0 & $71,04 \pm 15,57$ & 5,54 & $0,00^{*}$ \\
\hline
\end{tabular}

*: $\mathrm{p} \leq 0,05$ F: One-Way ANOVA

Çalışma sonucunun literatürdeki çalışma bulgularından kısmen farklı olmasının nedeni farklı örneklem gruplarında yapılmasından kaynaklanmaktadır.

Çocuğun duygusal ve ruhsal işlevlerine zarar verici nitelikte süreğen davranış ve etkileşim örüntüleri şeklinde tanımlanan duygusal istismar aşağılama, alay etme, çocuğu reddetme, tehdit etme, tek başına bırakma, yıldırma, kendi çıkarına kullanma, vaktinden önce yetişkin rolü verme gibi davranışları kapsamaktadır. ${ }^{16,20} \mathrm{Bu}$ çalışmada çocukluğunda aileleri tarafindan bazen veya her zaman toplum içinde küçük düşürme, aşağılama ve tehdit edilme oran $1 \% 23$ 'tür. Koç ve ark. (2015)'nın üniversite öğrencileri ile yaptıkları kesitsel çalışmada ailesi tarafından tehdit edilme oranı \%17,6 olarak bildirilmiștir. ${ }^{21}$ Bilge ve ark. (2013) çalışmasında ailelerin \%31,5'inin çocuklarını tehdit ettiği belirlenmiştir. ${ }^{19}$ Çalışma verilerinin birbiriyle farklılık göstermesinin nedeni duygusal istismarı değerlendiren standart formların olmamasıdır. $\mathrm{Bu}$ durum çalışmalar arasında sistemli bir karşılaştırma yapılmasını engellemektedir.

Çalışmada öğrencilerin çocukluk döneminde ihmal ve istismar edilme durumları geriye dönük olarak sorgulanmış ve öğrencilerin çocukluk döneminde en çok (\%81) bağırılıp azarlanmaya maruz kaldıkları belirlenmiştir. Yapılan çalışmalarda çocuğa bağırmak \%75-80 oranında bulunmuş olup, en sık görülen istismar türünün duygusal istismar olduğu 
saptanmıştır. ${ }^{22,23}$ Ayrıca Çetinkaya (2013)'nın çalışmasında üniversite öğrencilerinin \%35,3'ü sözel şiddete, $\% 42,3$ '̈u duygusal şiddete maruz kaldıklarını ya da şahit olduklarını ifade etmişlerdir. ${ }^{17}$ Araştırmadan elde edilen bulgular literatür bilgisiyle uyumluluk göstermektedir.

Literatürde, benlik saygısının yaşla birlikte arttığ1 buna karşılık benzer yaş gruplarında bulunan bireylerde benlik saygısının yaşa göre anlamlı farklılık göstermediği belirtilmektedir. ${ }^{24} \mathrm{Bu}$ çalışmada benlik saygısı ölçek puanı ile ilişkili faktörler de değerlendirilmiştir. CBSÖ toplam puan ortalaması ile yaş grupları (20 ve alt1; 21 ve üzeri) karşılaştırıldığında istatistiksel olarak anlamlı ilişkinin olmadığı belirlenmiştir. Benzer şekilde Erbil ve ark. (2006) ve Eraslan ve ark. (2015) çalışmasında da yaş grupları ile ölçek puan ortalaması arasında ilișki saptanmamıștır. ${ }^{24,25} \mathrm{Bu}$ çalıșmadan elde edilen veriler literatür bilgisiyle uyumluluk göstermektedir.

Literatürde çocuk sayısı azaldıkça ailedeki çocukların benlik saygısı düzeylerinin daha yüksek olduğu ifade edilmiştir. ${ }^{13}$ Torun ve ark. (2012), Dinçer ve Öztunç (2009), Karadağ ve ark. (2008) çalışmalarında öğrencilerin kardeş sayısı azaldıkça CBSÖ düzeyinin anlamlı şekilde

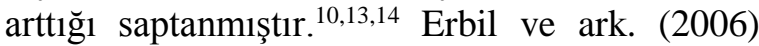
çalışmasında ise benzer şekilde kardeş sayısı 2 'den fazla olduğu durumda benlik saygısı puanın düştüğü belirlenmiştir. ${ }^{25} \mathrm{Bu}$ çalışmada CBSÖ puanı ile kardeş sayısı arasında anlamlı bir ilişkiye rastlanmamıştır. Bu çalışmadan elde edilen verilerin literatür bilgisiyle uyumluluk göstermemesinin nedeni örneklem grubunun farkl1 özelliklere sahip olmasından kaynaklanabilir.

\section{SONUÇ VE ÖNERILLER}

Sonuç olarak; çalışma grubumuzda kız öğrencilerin benlik saygısı ortalamasının orta düzeyde olduğu; duygusal ve fiziksel yönden ihmal edilen öğrencilerin bulunduğu ve bu öğrencilerin benlik saygılarının istatistiksel olarak anlamlı şekilde daha düşük olduğu belirlenmiştir.

Çocuk istismarı ve ihmalinin tespit, tedavi ve rehabilitasyonunda tıp, hukuk ve sosyal hizmetler alanlarının işbirliği içinde çalışması ve multidisipliner bir yaklaşım benimsenmesi gerekmektedir.

Elde edilen sonuçlar doğrultusunda

önerilerimiz;

Çocuk yetiştirme ve gelişim evreleri hakkında ebeveynlere eğitim verilmesi,

Aile içi iletişimin arttırılması,

İlköğretim kurumlarında görevli personelin ihmal ve istismarın fark edilmesi ve gerekli müdahalenin yapılması konusunda hizmet içi eğitimden geçirilmesi,

Sağlik personelinin herhangi bir nedenle hastaneye başvuran çocukların ihmali ve istismarını göz önünde bulundurması,

Ülke politikasının çocuk istismar1/ihmalini önleyecek şekilde yeniden yapılandırılmasıdır.

\section{ARAŞTIRMANIN SINIRLILIKLARI}

Örneklem sayısının yetersiz olması, grubun sadece k1z öğrencilerden oluşması, verilerin kişilerin kendi beyanına dayanması ve verilerin toplanmasında ihmal ve istismara yönelik standart veri toplama araçlarının olmaması çalışmanın sinırlılıkları arasında yer almaktadır.

\section{KAYNAKLAR}

1. Bahar G, Savaş H, Bahar A. Çocuk istismarı ve ihmali: Bir gözden geçirme. Fırat Sağlık Hizmetleri Dergisi 2009;4(12):51-65.

2. World Health Organization. (WHO) Child maltreatment [İnternet], 2014. [updated 2014 Dec; cited 2015 Jun 26]. Available from: http://www.who.int/mediacentre/factsheets/f s150/en/

3. Kara B, Biçer Ü, Gökalp AS. Çocuk istismarı. Çocuk Sağlığı ve Hastalıkları Dergisi 2004;47: 140-151.

4. Armağan E. Çocuk ihmâlî ve istismarı: psikoz tablosu sergileyen bir istismar olgusu. Yeni Symposium Dergisi 2007;45(4):170173.

5. Irmak TY. Çocuk istismarı ve ihmalinin yaygınlığı ve dayanıklılıkla ilişkili faktörler. [Yayınlanmamış Doktora Tezi]. Ege Üniversitesi Sosyal Bilimler Enstitüsü, Psikoloji Anabilim Dalı, İzmir, Türkiye, 2008.

6. Kaya İ, Çeçen-Eroğul AR. Ergenlerde çocukluk dönemi istismar yaşantılarının 
yordayıcısı olarak aile işlevlerinin rolü. Eğitim ve Bilim 2013;38(168):386-397.

7. Eti Aslan F. Beden imajında değişiklik deneyimleyen hastalara yönelik hemşirelik yaklaşımları. Çınar Dergisi 1998;2:4-6.

8. Kahriman İ. Karadeniz Teknik Üniversitesi Trabzon Sağlık Yüksekokulu öğrencilerinin benlik saygıları ve atılganlık düzeylerinin bazı değişkenler açısından incelenmesi. Cumhuriyet Üniversitesi H.Y.O. Dergisi 2005;9(1):24-32.

9. Taysi E. Benlik saygısı, arkadaşlar ve aileden sağlanan sosyal destek [Yüksek Lisans Tezi ]. Ankara Üniversitesi Sosyal Bilimler Enstitüsü, Psikoloji Anabilim Dalı, Ankara, Türkiye, 2000.

10. Karadağ G, Güner İ, Çuhadar D, Uçan Ö. Gaziantep Üniversitesi Sağlık Yüksekokulu öğrencilerinin benlik saygıları. Fırat Sağlık Hizmetleri Dergisi 2008;3(7):29-42.

11. Durmuşoğlu N, Doğru S. Çocukluk örseleyici yaşantılarının ergenlikteki yakın ilişkilerde bireye etkisinin incelenmesi. Selçuk Üniversitesi Sosyal Bilimler Enstitüsü Dergisi 2006;15:237-247.

12. Tufan B, Turan N. Coopersmith Benlik Saygısı Ölçeği üzerinde geçerlik, güvenirlik çalışması. 23. Ulusal Psikiyatri ve Nörolojik Bilimler Kongre Kitabı, İstanbul; 1987.s.816-817.

13. Dinçer F, Öztunç G. Hemşirelik ve ebelik ögrencilerinin benlik saygısı ve atılganlık düzeyleri. Sağlık Bilimleri Fakültesi Hemşirelik Dergisi 2009:22-33.

14. Torun S, Arslan S, Nazik E, Akbaş M, Yalçın SÖ. Hemşirelik öğrencilerinin benlik saygısı ve boyun eğici davranışlarının incelenmesi. Cumhuriyet Tip Dergisi 2012;34:399-404.

15. Özkan Aİ, Özen A. Öğrenci hemşirelerde boyun eğici davranışlar ve benlik saygısı arasındaki ilişki. TSK Koruyucu Hekimlik Bülteni 2008;7(1):53-58.

16. Beyazıt U. Çocuk istismarı konusunda Türkiye'de yapılan lisansüstü tezlerin incelenmesi. Hacettepe Üniversitesi Sağlık Bilimleri Fakültesi Dergisi 2015;1(1).

17. Çetinkaya SK. Üniversite öğrencilerinin şiddet eğilimlerinin ve toplumsal cinsiyet rollerine ilişkin tutumlarının incelenmesi. Nesne Psikoloji Dergisi 2013;1(2):21-43.
18. Ayan S. Okulda disiplin cezası alma, ailede şiddete uğrama. Anadolu Psikiyatri Dergisi 2011;12:137-142.

19. Bilge YD, Taşar MA, Kılınçoğlu B, Özmen S, Tıraş Ü. Alt sosyoekonomik düzeye sahip anne-babaların çocuk istismarı ve ihmali hakkındaki bilgi düzeyleri, deneyimleri ve kullandıkları disiplin yöntemleri. Anadolu Psikiyatri Dergisi 2013;14:27-35.

20. Türkiye'de Çocuk İstismarı ve Aile İçi Şiddet Araştırması [İnternet], 2010. (Erişim tarihi: 31.07.2015) Erişim Adresi: www.unicef.org.tr/files/bilgimerkezi/doc/c ocuk-istismari-raporu-tr.pdf

21. Koç EM, Şahin Ö, Güngör E, Dağlı FŞ, Derman O. Çocuk istismarı ve ihmalini önleme derneği gençlik kolu gönüllülerinin çocukluk dönemlerindeki istismar sıklığı. STED 2015:24(4):135-141.

22. Runyan D, Corrine W, Ikeda R, Hassan F, Ramiro L. Child abuse and neglect by parents and other caregivers. İn:. Krug EG, Dahlberg LL, Mercy JA, Eds. World Report On Violence And Health, World Health Organization, Geneva: 2002.p.59-86.

23. Topbas M. İnsanlığın büyük bir ayıbı: çocuk istismarı. TSK Koruyucu Hekimlik Bülteni 2004; 3(4):76-80.

24. Eraslan M, Çalışkan G, Baş M. Beden eğitimi ve spor yüksekokulu öğrencilerinin benlik saygılarının yaş, cinsiyet ve spor yapma durumlarına göre incelenmesi. Uluslararası Multidisipliner Akademik Araştırmalar Dergisi 2015;2(1):48-54.

25. Erbil N, Divan Z, Önder P. Ergenlerin benlik saygısına ailelerinin tutum ve davranışlarının etkisi. Aile ve Toplum 2006;3(10):7-15. 